\title{
Importance of the macrofauna for the feeding of young fish species from Infralittoral of Arrozal - Cananéia lagoon estuarine region $\left(25^{\circ} 02^{\prime} \mathrm{S}-47^{\circ} 56^{\prime} \mathrm{W}\right)$ - Brazil
}

\author{
Yoko WAKABARA; Airton S. TARARAM \& Maurea N. FLYNN \\ Instituto Oceanográfico da Universidade de São Paulo \\ (Caixa Postal 9075, 01065-970 São Paulo, SP, Brasil)
}

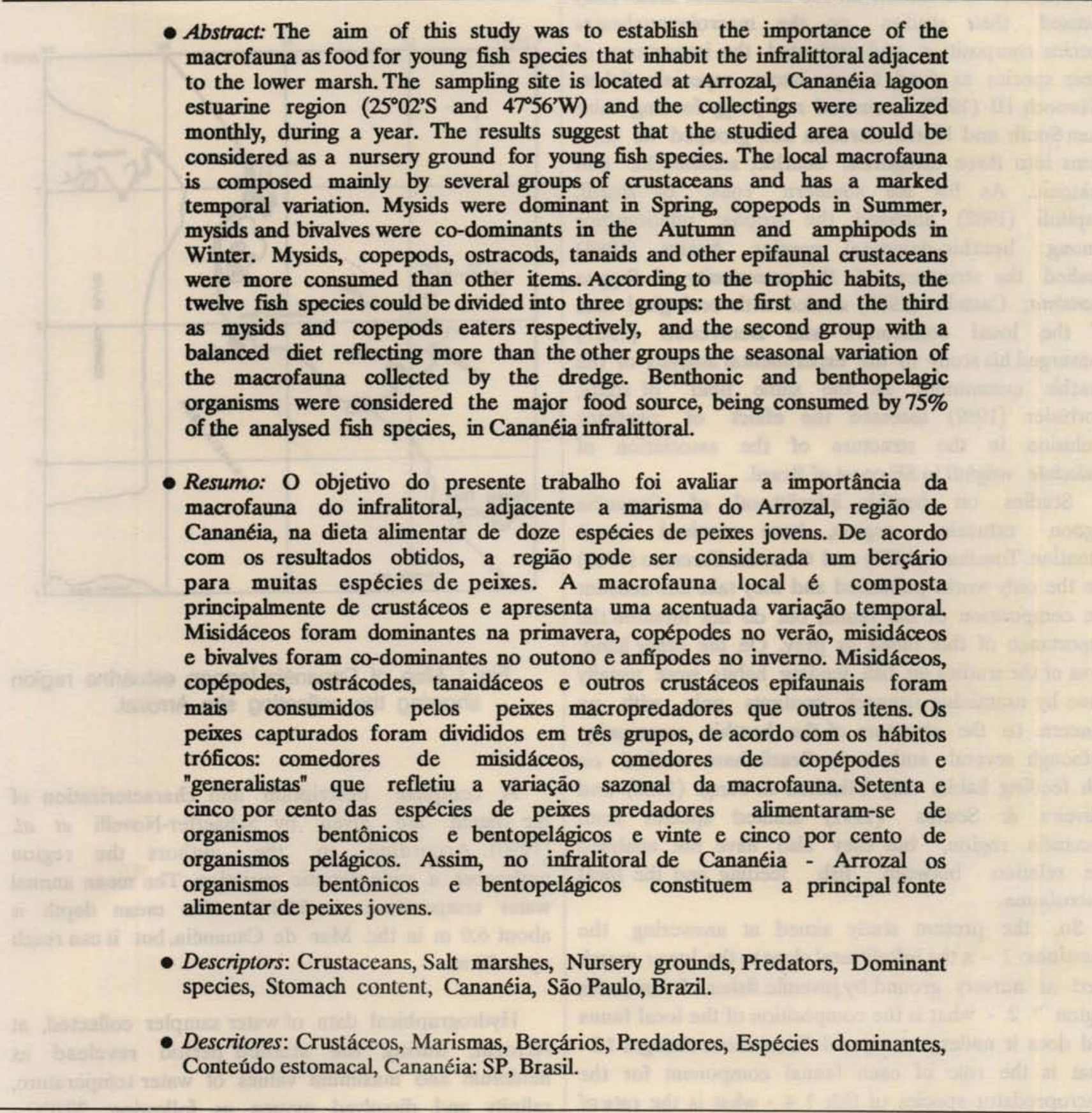

Contr. no. 752 do Inst. oceanogr. da Usp. 


\section{Introduction}

The fauna living around estuarine marsh vegetation could represent necessary or supplementary food items for the local fish fauna and other predators.

At estuarine regions, particularly in areas of macrophyta growing emphasis has been given to their role as nurseries ground for juvenile fishes (Livingston, 1982; Poxton et al., 1983; Boddeke et al., 1986; Raffaelli \& Milne, 1987; Hettler Jr., 1989).

Recently Lasiak (1984), Jones (1986), Dauvin (1988), Brewer et al. (1991) have published considerable information on the infralittoral area. They focused their studies on the macroinvertebrates species composition and evaluated the importance of these species as food for predators, especially fishes. Manooch III (1977) examined red porgy feeding habit from South and North Carolina and grouped its food items into three categories: benthic, semibenthic and nektonic. As for the southern coast of Brazil, Capitoli (1982) analysed the trophic relationships among benthic-demersal species, Asmus (1984) studied the structure of the community of Ruppia maritima; Castello (1985) dealed with ecological data of the local consumers and Bemvenuti (1987) converged his study to the experimental analysis of the benthic community. In the same field of study, Corbisier (1989) assessed the effect of predator exclusion in the structure of the association of Halodule wrightii in SE coast of Brazil.

Studies on benthic infralittoral of Cananeia lagoon estuarine region, have received scant attention. Tommasi (1970) and Guzmán-Carcamo (1980) are the only works published and they take into account the composition of the fauna, but do not mention the importance of this fauna as prey. On the other hand, most of the studies on fish feeding habits were usually done by examining stomach contents only, with no concern to the structure of the benthic community. Although several authors in Brazil have worked on fish feeding habits only Mishima \& Tangi (1982) and Oliveira \& Soares (1991) studied species from Cananeia region, but they also have not analysed the relation between fish feeding and the local macrofauna.

So, the present study aimed at answering the questions: 1 - is the infralittoral close to the lower marsh used as nursery ground by juvenile fishes of Cananéia region ? 2 - what is the composition of the local fauna and does it undergo temporal fluctuations changes ? 3 what is the role of each faunal component for the macropredator species of fish ? 4 - what is the rate of predation imposed by each species on benthonic/benthopelagic or pelagic organisms?

\section{Studied area}

The area is located at Arrozal, Cananeia on the southern coast of São Paulo State (2502'S-47'56'W) (Fig. 1). Information concerning physical, chemical, geological and climatological data of Cananéia lagoon estuarine region has been recorded by several authors (Besnard, 1950; Garcia-Occhipinti, 1959; 1963; Magliocca \& Kutner, 1964; Miyao, 1977; Tessler, 1982; Mishima et al., 1985; Miyao et al., 1986).

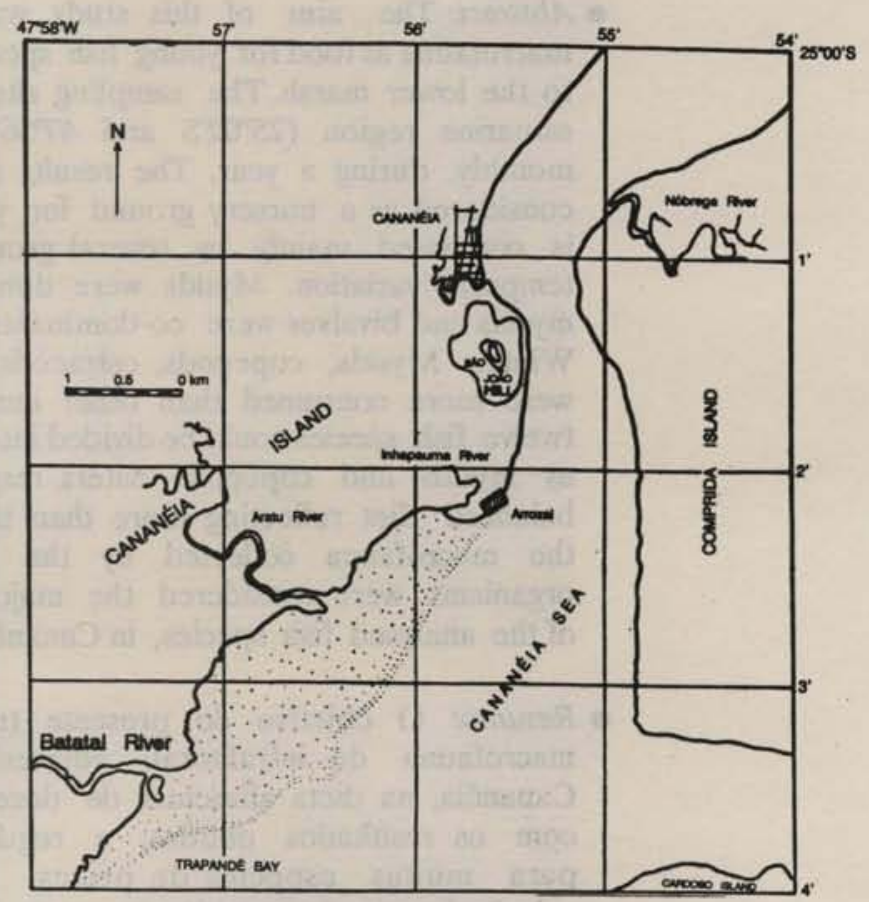

Fig. 1. Map of Cananéia lagoon estuarine region showing the collecting site Arrozal.

A complete description and characterization of the system are given by Schaeffer-Novelli et al. (1990). According to the authors the region undergoes a wide climatic variation. The mean annual water temperature is $23.8^{\circ} \mathrm{C}$. The mean depth is about $6.0 \mathrm{~m}$ in the Mar de Cananéia, but it can reach up to $20 \mathrm{~m}$.

Hydrographical data of water sampler collected, at Arrozal, during the studied period revelead as minimum and maximum values of water temperature, salinity and dissolved oxygen as following: $20.0^{\circ} \mathrm{C}$ $32.0^{\circ} \mathrm{C} ; 25.94-32.51$ and $3.86 \mathrm{ml} / \mathrm{l}-5.98 \mathrm{ml} / \mathrm{l}$. 
Reise (1985) recorded that in the sheltered coast of the tropics, mangroves replace saltmarshes or both may occur simultaneously. This is the case of Cananeia with its $90 \mathrm{~km}^{2}$ of coast dominated mainly by mangroves, most of them bordered in front by a narrow belt of saltmarsh. Arrozal is a sheltered shore with one of the largest marshes in the region (Takeda, 1988), its low-marsh extending down towards the infralittoral. Here plants of Spartina altemiflora appear in a very low density sparcely arranged, their roots diminishing the mobility of the sediment and their leaves providing shelter from waves and tidal currents for the organisms living there. The depth of the surveyed area was. between 1-3 m (Fig. 2).

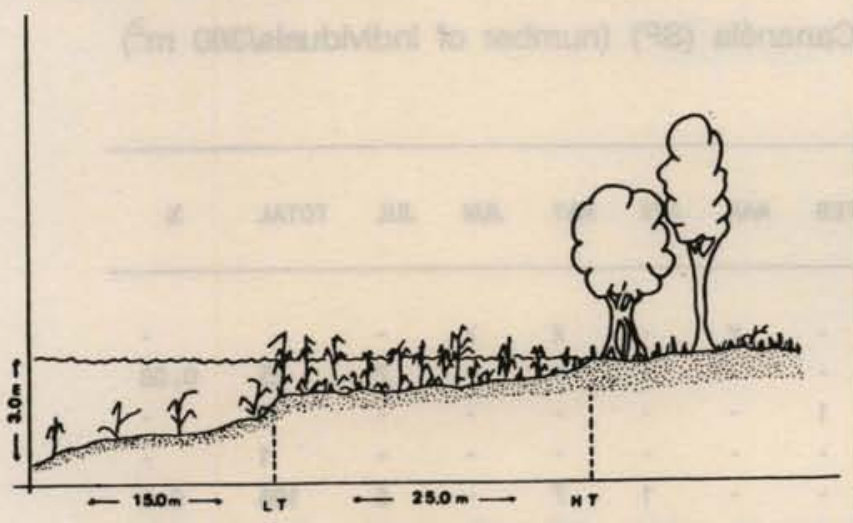

Fig. 2. Schematic figure in profile of the sampling area. Arrozal - Cananéia (LT = low tide, $\mathrm{HT}=$ high tide).

\section{Material and methods}

Water temperature, dissolved oxygen and salinity were recorded at each sampling. Dissolved oxygen was analysed according to Strickland \& Parsons (1968) and salinity was determined using a hand refractometer.

The infralittoral macrofauna was surveyed with a small dredge once a month during August/81 - July/82. The sampling gear (Fig. 3) consisted of a steel framework weighing about $5.5 \mathrm{~kg}$ and a nylon bag with $0.5 \mathrm{~mm}$ stretch mesh fixed from the inside. Fifteen-minutes tows were made at each $15 \mathrm{~m}$ long transect, perpendicularly to the water line. Six transects were sampled monthly corresponding to approximately $360 \mathrm{~m}^{2}$. Fishes were captured using a $16 \mathrm{~m}$ casting net towed from the boat (height $3 \mathrm{~m}$ and $3 \mathrm{~cm}$ stretch mesh) and a $15 \mathrm{~m}$ set net, $1.30 \mathrm{~m}$ height and $2 \mathrm{~cm}$ stretch mesh.

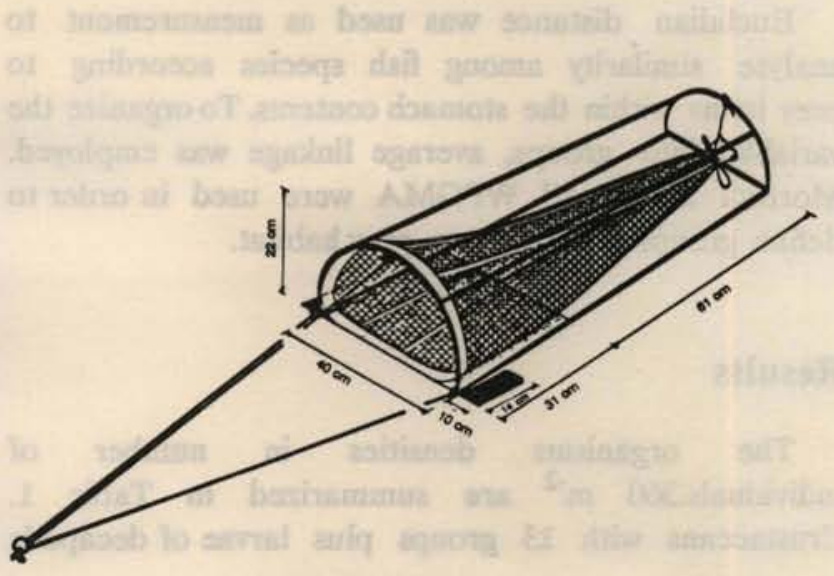

Fig. 3.Schematic drawing of the sampling dredge.

Macrofaunal sampling was washed through a sieve of 500 micra mesh size and preserved in $70 \%$ alcohol. The fauna was sorted under a binocular microscope and specimens of each group were counted. After capture, fishes were preserved in an ice bag until transferred to the laboratory. There, species identification, measurements of length and weight were determined for each specimen. Stomachs were removed, labeled and preserved in $6 \%$ formalin. The preserved material was drained, washed in tap water and stored in $70 \%$ alcohol. Stomachs were dissected out longitudinally and the contents placed in a bowl for examination using a binocular microscope. Both full and empty stomachs were counted. Food items were identified to the group level (different level of taxon). Since some foods were partially digested and usually crushed by fish teeth, the exact number of each taxon, in some cases, could not be determined. For numerical analyses and presentation of the results, some uncountable items such as plants and bryozoans were not considered. Partially destroyed fragments were estimated and included in the countings being each fragment considered as one specimen. Results of each macrofauna category contained in the digestive tracts of fishes were tabulated and given as percentual frequency of occurrence.

For the analyses and presentation of data, monthly samples were grouped as follows: Spring (October - December); Summer (January - March); Autumn (April - June) and Winter (July - September).

Relative frequency of occurrence (\%) was obtained by dividing the number of stomachs containing the specific item by the total number of each fish species. For quantitative analyses only fish species with at least two specimens in average, collected in each sample were considered, according to Jackson index (1972). 
Euclidian distance was used as measurement to analyse similarity among fish species according to prey items within the stomach contents. To organize the variables into groups, average linkage was employed. Morisita index and WPGMA were used in order to define groups according to prey habitat.

\section{Results}

The organisms densities in number of individuals. $360 \mathrm{~m}^{-2}$ are summarized in Table 1. Crustaceans with 13 groups plus larvae of decapods were the most well represented among all sampled groups. A total of 28,442 organisms representing 24 groups of flora and fauna were identified. Mysids accounted for $82.4 \%$ of all individuals. Figure 4 shows the faunal-composition during the study period.

Though most of these groups were present throughout the year, marked fluctuations were evident, as shown in Figure 5. During the Spring mysids reached $98.3 \%$ of the total fauna. Other groups such as nemerts, gastropods, bivalves, polychaetes, ostracods, copepods, dendrobranchiates, caridean shrimps, anomuran and brachyuran crabs,

Table 1. Density of organisms collected at Arrozal, Cananéia (SP) (number of individuals/360 $\mathrm{m}^{2}$ )

\begin{tabular}{|c|c|c|c|c|c|c|c|c|c|c|c|c|c|c|}
\hline GROUPS & AUG & SEPT & oct & NOV & DEC & JAN & FEB & MAR & APR & MAY & JUN & JUL & TOTAL & \% \\
\hline ALGAE(MACROSC.) & $x$ & $x$ & $x$ & $\mathbf{x}$ & $x$ & - & - & $\mathbf{x}$ & - & $\mathrm{x}$ & $x$ & - & - & - \\
\hline CNIDARIA & - & 22 & - & - & - & - & - & - & - & 1 & - & 2 & 25 & 0.08 \\
\hline NEMERTEA & - & - & 1 & - & - & - & 1 & - & - & - & - & - & 2 & - \\
\hline MEMATODA & - & 1 & - & - & - & - & - & - & - & - & - & - & 1 & - \\
\hline GASTROPODA & 75 & - & 8 & - & - & 9 & - & - & 1 & 7 & - & 6 & 106 & 0.4 \\
\hline BIVALVIA & 224 & 5 & 49 & 5 & 31 & 16 & 3 & 35 & 104 & 37 & 20 & 60 & 589 & 2.0 \\
\hline POLYYCHAETA & 116 & 45 & 9 & 3 & 8 & 26 & 27 & 54 & 26 & 2 & 6 & 39 & 361 & 1.3 \\
\hline OSTRACOOA & 165 & 4 & 6 & - & 40 & - & 1 & 20 & 3 & - & 1 & 4 & 244 & 0.8 \\
\hline COPEPODA & 21 & 197 & 6 & - & 9 & - & - & 303 & - & 59 & 18 & 16 & 629 & 2.2 \\
\hline CIRRIPEDIA & - & - & - & - & - & - & - & - & 1 & - & - & - & 1 & - \\
\hline DENDROBRANCHIATA & - & 10 & 3 & 48 & 67 & 14 & 4 & 10 & 7 & 11 & 6 & 1 & 181 & 0.6 \\
\hline CARIDEA & 1 & 12 & 4 & 1 & 3 & 14 & 46 & 13 & 7 & 59 & 14 & 20 & 194 & 0.7 \\
\hline THALASSINIDEA & - & - & - & - & - & - & - & 1 & - & - & - & - & 1 & - \\
\hline ANOMURA & - & 1 & - & - & 1 & 2 & - & - & 1 & 2 & - & 1 & 8 & - \\
\hline BRACHYURA & 5 & 4 & 5 & 1 & 7 & 4 & 3 & 7 & 2 & 7 & 15 & 1 & 61 & 0.2 \\
\hline DECAPODA LARVAE & - & - & - & - & 2 & - & - & - & - & - & - & - & 2 & - \\
\hline MYSIDACEA & 89 & 643 & 5116 & 15010 & 2243 & 9 & 8 & 32 & - & 11 & 144 & 255 & 23560 & 82.8 \\
\hline CUMACEA & 1 & 1 & - & - & - & - & - & - & - & - & - & - & 2 & - \\
\hline TANAIDACEA & 12 & 33 & - & - & - & - & - & 5 & 17 & 23 & 32 & 33 & 155 & 0.5 \\
\hline ISOPCOA & 48 & 13 & 1 & 3 & 1 & 8 & 4 & 6 & - & 11 & 14 & 2 & 111 & 0.4 \\
\hline AMPHIPODA & 1944 & 40 & 7 & 3 & 1 & 2 & 1 & 6 & 4 & 8 & 3 & 6 & 2025 & 7.1 \\
\hline SIPUNCULA & 1 & - & - & - & - & - & - & - & - & - & - & - & 1 & - \\
\hline CHAETOGNATA & - & 46 & - & 1 & 5 & - & - & - & - & 64 & - & - & 116 & 0.4 \\
\hline PISCES & 1 & 5 & 1 & 44 & 4 & 1 & 5 & 2 & 1 & 3 & - & - & 67 & 0.2 \\
\hline TOTAL & 2703 & 1082 & 5216 & 15119 & 2422 & 105 & 103 & 494 & 174 & 305 & 273 & 446 & 28442 & 100 \\
\hline
\end{tabular}




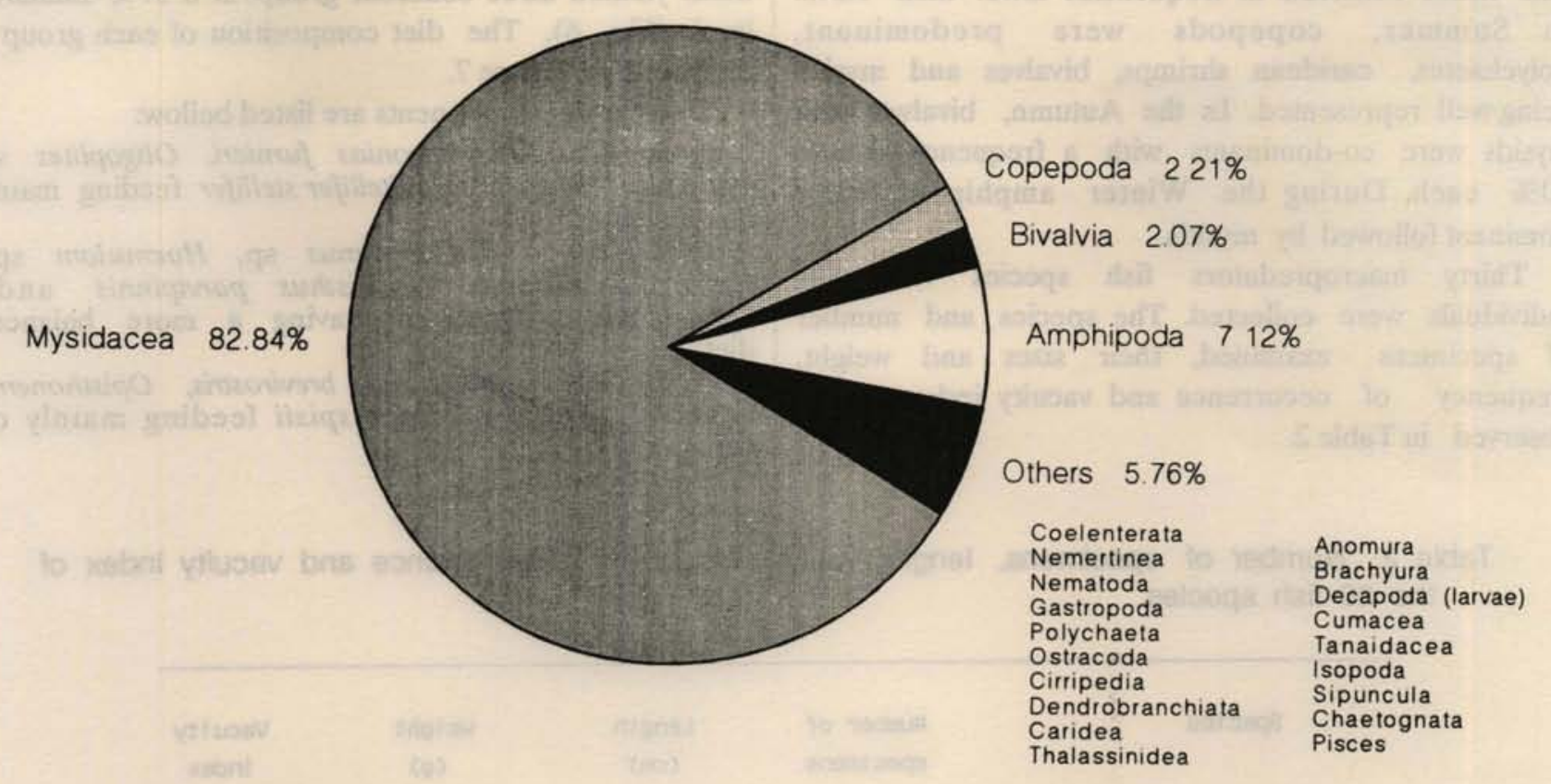

Fig. 4. Percentual composition of the fauna sampled during August/81 - July/82 at Arrozal.

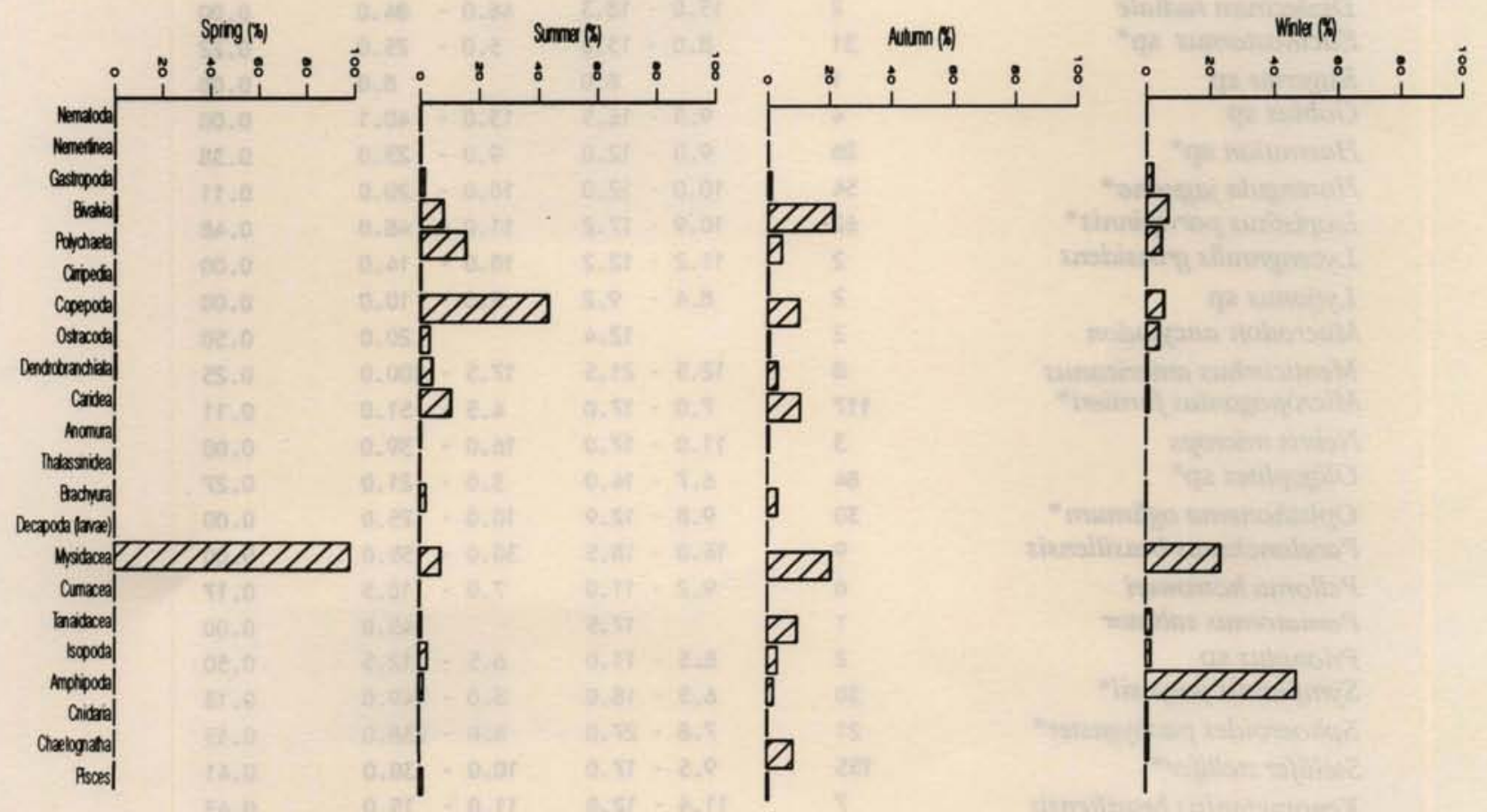

Fig. 5. Faunal composition during the annual seasons. 
larvae of decapods, isopods, amphipods, chaetognaths and fishes occurred in frequencies lower than $1.0 \%$. In Summer, copepods were predominant, polychaetes, caridean shrimps, bivalves and mysids being well represented. In the Autumn, bivalves and mysids were co-dominants with a frequency around $20 \%$ each. During the Winter amphipods were dominant followed by mysids.

Thirty macropredators fish species with 874 individuals were collected. The species and number of specimens examined, their sizes and weight, frequency of occurrence and vacuity index can be observed in Table 2.
Cluster analysis based on the similarity of food items yielded three coherent groups at a $57 \%$ similarity level (Fig. 6). The diet composition of each group is displayed in Figure 7.

Each group components are listed bellow:

- group I - Micropogonias furnieri, Oligoplites sp, Symphurus jenynsii and Stellifer stellifer feeding mainly on mysids;

- group II - Eucinostomus sp, Haemulom sp, Harengula jaguana, Isopisthus parvipinnis and Sphoeroides pachygaster having a more balanced diet;

- group III - Anchoviella brevirostris, Opisthonema oglimum and Cathorops spixii feeding mainly on copepods.

Table 2. Number of specimens, length, weight, frequency of occurrence and vacuity index of the 30 fish species

\begin{tabular}{|c|c|c|c|c|}
\hline Species & $\begin{array}{l}\text { Number of } \\
\text { spec imens }\end{array}$ & $\begin{array}{l}\text { Length } \\
(\mathrm{cm})\end{array}$ & $\begin{array}{l}\text { We ight } \\
\text { (g) }\end{array}$ & $\begin{array}{c}\text { Vacuity } \\
\text { index }\end{array}$ \\
\hline Anchoa spinifera & 1 & 14.3 & 20.0 & 0.00 \\
\hline Anchoviella brevirostris* & 29 & $6.2-11.0$ & $3.0-$ & 0.00 \\
\hline Cathorops spixii* & 64 & $10.0-19.8$ & $12.0-39.5$ & 0.08 \\
\hline Centropomus sp & 7 & $16.8 \cdot 24.5$ & $45.0-167.0$ & 0.14 \\
\hline Cetengraulis sp & 6 & $10.4-35.0$ & $10.0-35.0$ & 0.00 \\
\hline Chloroscombrus crysurus & 4 & $7.4-8.0$ & $5.0-8.0$ & 0.25 \\
\hline Cynoscion leiarchus & 10 & $11.5-30.0$ & $17.0-267.0$ & 0.30 \\
\hline Diplectrum radiale & 2 & $15.0-18.3$ & $46.0-84.0$ & 0.00 \\
\hline Eucinostomus $\mathrm{sp}^{*}$ & If $\rightarrow=4$ & $8.0-13.0$ & $5.0-25.0$ & 0.22 \\
\hline Eugerres sp & 1 & 8.0 & 8.0 & 0.00 \\
\hline Gobius sp & 4 & $9.5-16.5$ & $13.0-40.1$ & 0.00 \\
\hline Haemulon $\mathrm{sp}^{*}$ & 26 & $9.0-12.0$ & $9.0-$ & 0.38 \\
\hline Harengula jaguana* & 54 & $10.0-12.0$ & 10.0 & 0.11 \\
\hline Isopisthus parvipinnis* & 62 & $10.9-17.2$ & $11.0=$ & 0.48 \\
\hline Lycengraulis grossidens & 2 & $11.2-12.2$ & $10.0-$ & 0.00 \\
\hline Lytjanus sp & 2 & $8.4-9.2$ & $9.0=$ & 0.00 \\
\hline Macrodon ancylodon & 2 & 12.4 & 20.0 & 0.50 \\
\hline Menticirnhus americanus & 8 & $12.5-21.5$ & $17.5-100.0$ & 0.25 \\
\hline Micropogonias furnieri* & 117 & $7.0-17.0$ & $4.5-51.0$ & 0.11 \\
\hline Nebris microps & 3 & $11.0-17.0$ & $16.0-39.0$ & 0.00 \\
\hline Oligoplites $\mathrm{sp}^{*}$ & 84 & $6.7-14.0$ & $3.0-21.0$ & 0.27 \\
\hline Opisthonema oglimum* & 30 & $9.8-12.9$ & $10.0-25.0$ & 0.00 \\
\hline Paralonchurus brasiliensis & 9 & $16.0-18.5$ & $30.0-55.0$ & 0.00 \\
\hline Pelloma hcrroweri & 6 & $9.2-11.0$ & $7.0-10.5$ & 0.17 \\
\hline Pomatomus saltator & 1 & 17.5 & 45.0 & 0.00 \\
\hline Prionotus sp & 2 & $8.5-11.0$ & $6.5-12.5$ & 0.50 \\
\hline Symphurus jenynsii* & 30 & $6.5-18.0$ & $3.0-49.0$ & 0.13 \\
\hline Sphoeroides pachygaster* & 21 & $7.8-27.0$ & $8.0-238.0$ & 0.15 \\
\hline Stellifer stellifer* & 155 & $9.5-17.0$ & $10.0 \cdot 30.0$ & 0.41 \\
\hline Xenomelaniris brasiliensis & 7 & $11.4-12.8$ & $11.0-15.0$ & 0.43 \\
\hline
\end{tabular}

* = Species analysed quantitatively 


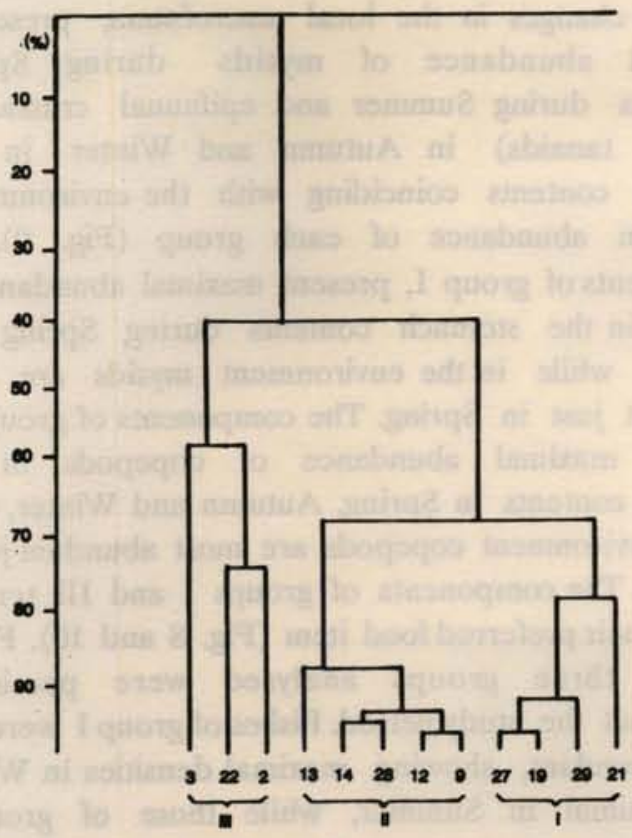

Group I

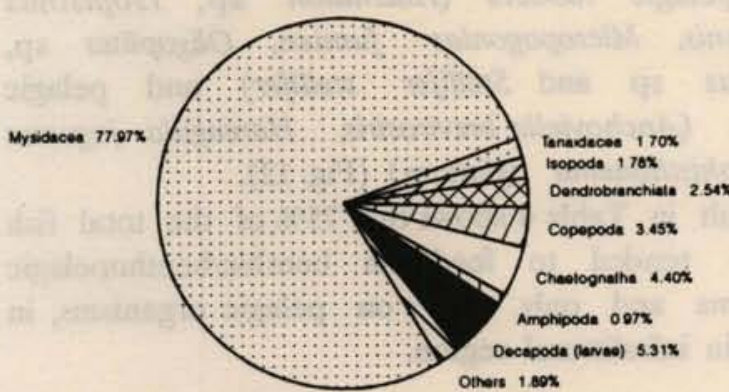

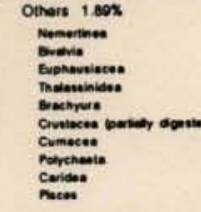

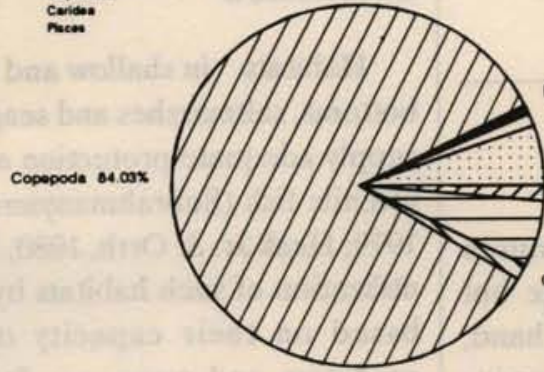

capoda (lenae) $0.87 x$

Cheotognatha $107 x$

Mysidaces $5.34 \times$

Isopode 1358

Ostracode $502 x$

Others $142 x$

nome lose

Dourcosed

condobir

incosace:

Fig. 7. Fishes diet compositiom: groups I, II and III. 
Considering the 30 fish species mysids were utilizied by 18 species, caridean shrimps by 17 , dendrobranchiates by 14 , amphipods by 14 , polychaetes by 12 , tanaids by 12 and copepods by 10 species of fish (Table 3).

Table 3. Food items and number of fish species, totalizing thirthy species, feeding on them $(\mathrm{B}=$ benthic, $\mathrm{BP}=$ benthopelagic and $P=$ pelagic)

Food items

Habitat Number of classification fish species

\begin{tabular}{|c|c|c|}
\hline Diatomacea & P & 1 \\
\hline Macroalgae & B & 3 \\
\hline Plants (except algae) & B & 2 \\
\hline Gastropoda & B & 4 \\
\hline Bivalvia & B & 5 \\
\hline Cephalopoda & $\mathbf{P}$ & 2 \\
\hline Polychaeta & B & 13 \\
\hline Ostracoda & BP & 6 \\
\hline Copepoda & $\mathbf{P}$ & 9 \\
\hline Copepoda - Harpacticoidea & B & 1 \\
\hline Cumacea & B & 1 \\
\hline Dendrobranchiata & BP & 15 \\
\hline Caridea & B & 16 \\
\hline Thalassinidea & B & 6 \\
\hline Brachyura & B & 4 \\
\hline Decapoda (larvae) & $\mathbf{P}$ & 5 \\
\hline Euphausiacea & $\mathbf{P}$ & 2 \\
\hline Mysidacea & BP & 19 \\
\hline Tana idacea & B & 12 \\
\hline Isopoda & B & 6 \\
\hline Anph ipoda & B & 13 \\
\hline Insecta & & 1 \\
\hline Bryozoa & B & 1 \\
\hline Chaetognatha & $\mathbf{P}$ & 5 \\
\hline Pisces & $P$ & 7 \\
\hline
\end{tabular}

Algae, cnidarians, nemerteans, barnacles, anomuran crabs and sipunculids were collected by the dredge but not found in the stomach contents. On the other hand, diatoms, plants, euphausiaceans, insects and bryozoans were found in the stomach contents analysis but were not sampled by the dredge.

The comparison between the macrofauna sampled and the stomach contents of each group of fish obtained by similarity analysis shows that only the components of group II have a diet reflecting the seasonal changes in the local macrofauna, presenting maximal abundance of mysids during Spring, copepods during Summer and epifaunal crustaceans (except tanaids) in Autumn and Winter in the stomach contents coinciding with the environmental maximum abundance of each group (Fig. 9). The components of group I, present maximal abundance of mysids in the stomach contents during Spring and Autumn while in the environment mysids are most abundant just in Spring. The components of group III present maximal abundance of copepods in the stomach contents in Spring, Autumn and Winter, while in the environment copepods are most abundant just in Summer. The components of groups I and III tend to stick to their preferred food item (Fig. 8 and 10). Fishes of the three groups analysed were persistent throughout the study period. Fishes of group I were the most abundant, showing maximal densities in Winter and minimal in Summer, while those of group II followed the same pattern, but were not so abundant. Fishes of group III presented maximal abundance in Winter, its abundance remaining almost constant during the rest of the year (Fig. 11).

Analysis of similarity of prey habitats allowed the grouping of the fishes into benthonic feeders (Cathorops spixii, Eucinostomus sp, Sphoeroides pachygaster), benthopelagic feeders (Haemulon sp, Isopisthus parvipinnis, Micropogonias fumieri, Oligoplites $\mathrm{sp}$, Prionotus sp and Stellifer stellifer) and pelagic feeders (Anchoviella brevirostris, Harengula jaguana and Ophisthonema oglimum) (Fig. 12).

Result in Table 4 shows that $75 \%$ of the total fish species tended to feed on benthic/benthopelagic organisms and only $25 \%$ on pelagic organisms, in Cananéia infralittoral region.

\section{Discussion}

Habitats in shallow and sheltered waters with grassy bottoms, saltmarshes and seagrass beds, are considered to supply adequate protection and food resources for many juvenile fish (Subrahmanyam \& Drake, 1975; Weinstein, 1979; Heck Jr. \& Orth, 1980; Boesh \& Turner, 1984). The utilization of such habitats by juvenile fishes seems to be based on their capacity of providing shelter from predators and numerous food items, particularly small crustaceans, which in turn utilize the plant detritus as their basic food. Huerta-Craig* (pers. commun.) has recorded about 123 fish species in Cananéia region and Zani-Teixeira (1983) lists 68 species caught at Trapandé

(*) Huerta-Craig, I. D. (1992) - Instituto Oceanográfico da USP. 


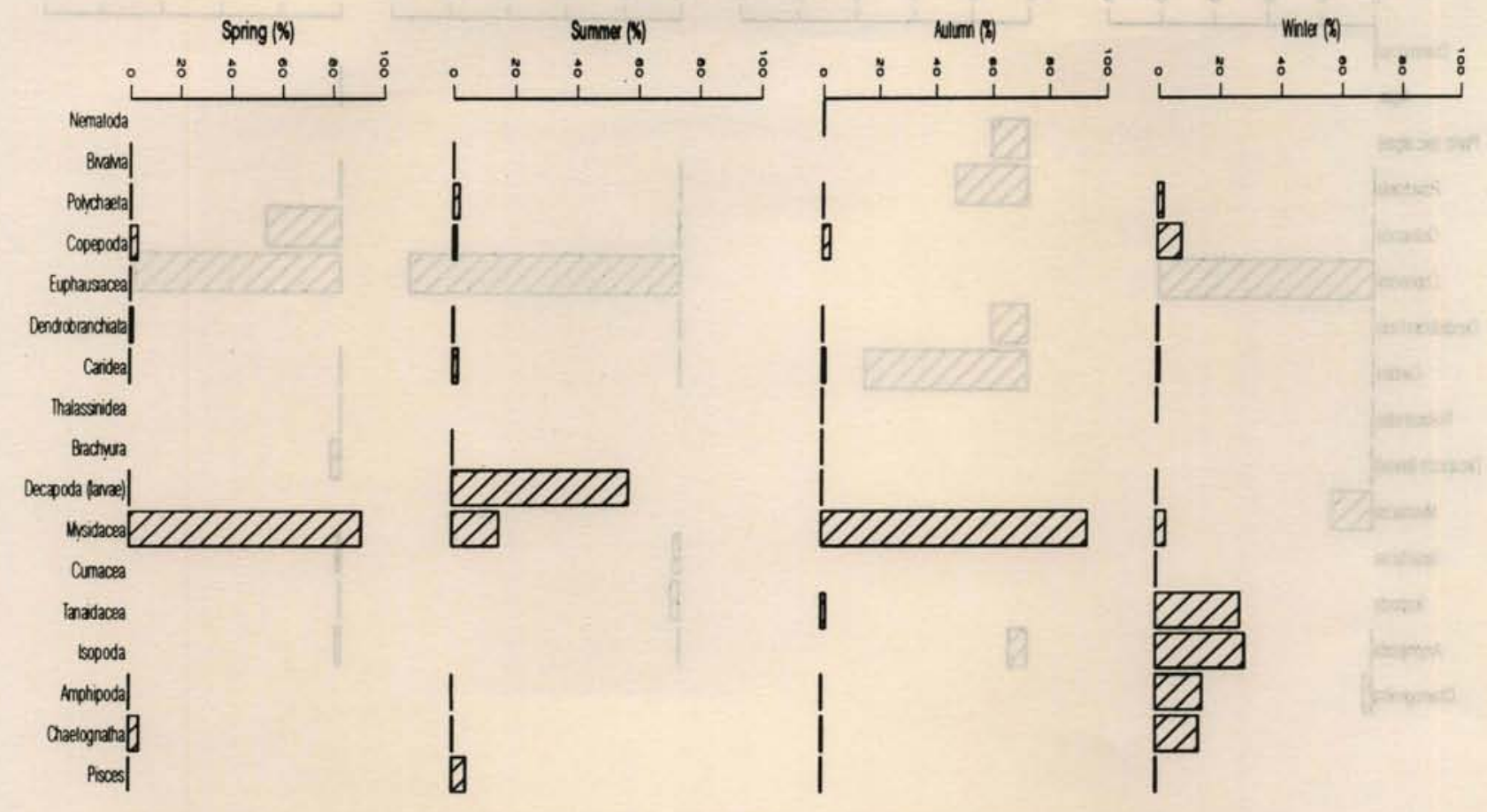

Fig. 8. Seasonal diet composition of Group I fishes.

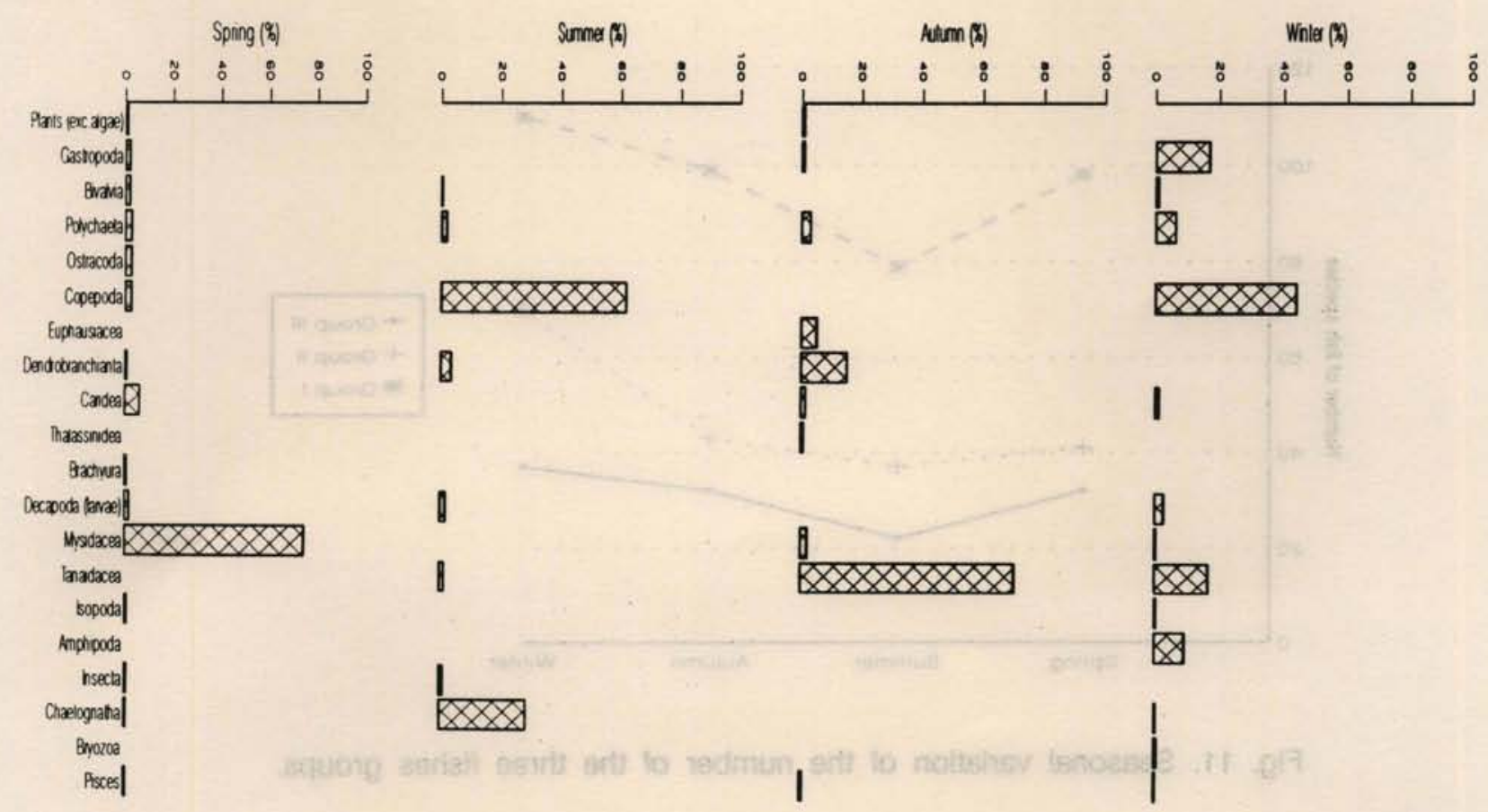

Fig. 9. Seasonal diet composition of Group II fishes. 


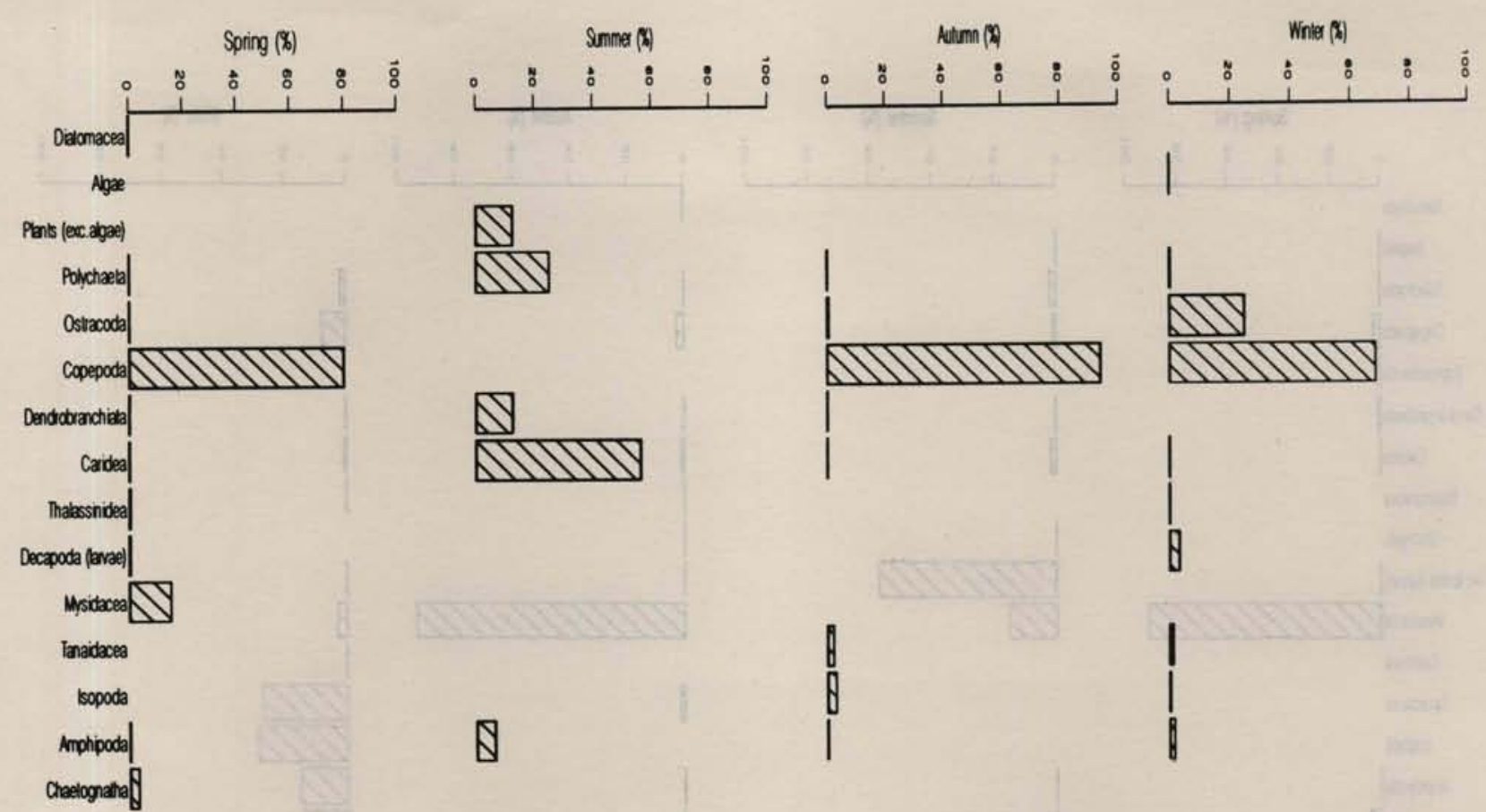

Fig. 10. Seasonal diet composition of Group III fishes.

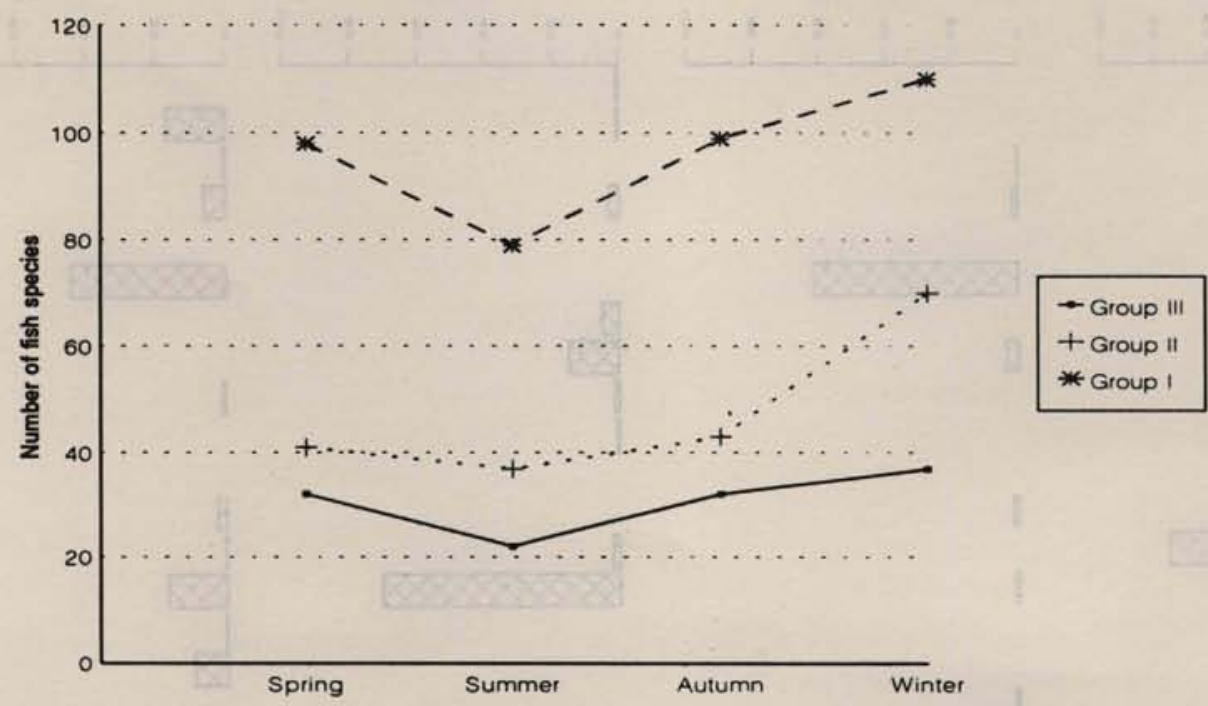

Fig. 11. Seasonal variation of the number of the three fishes groups. 


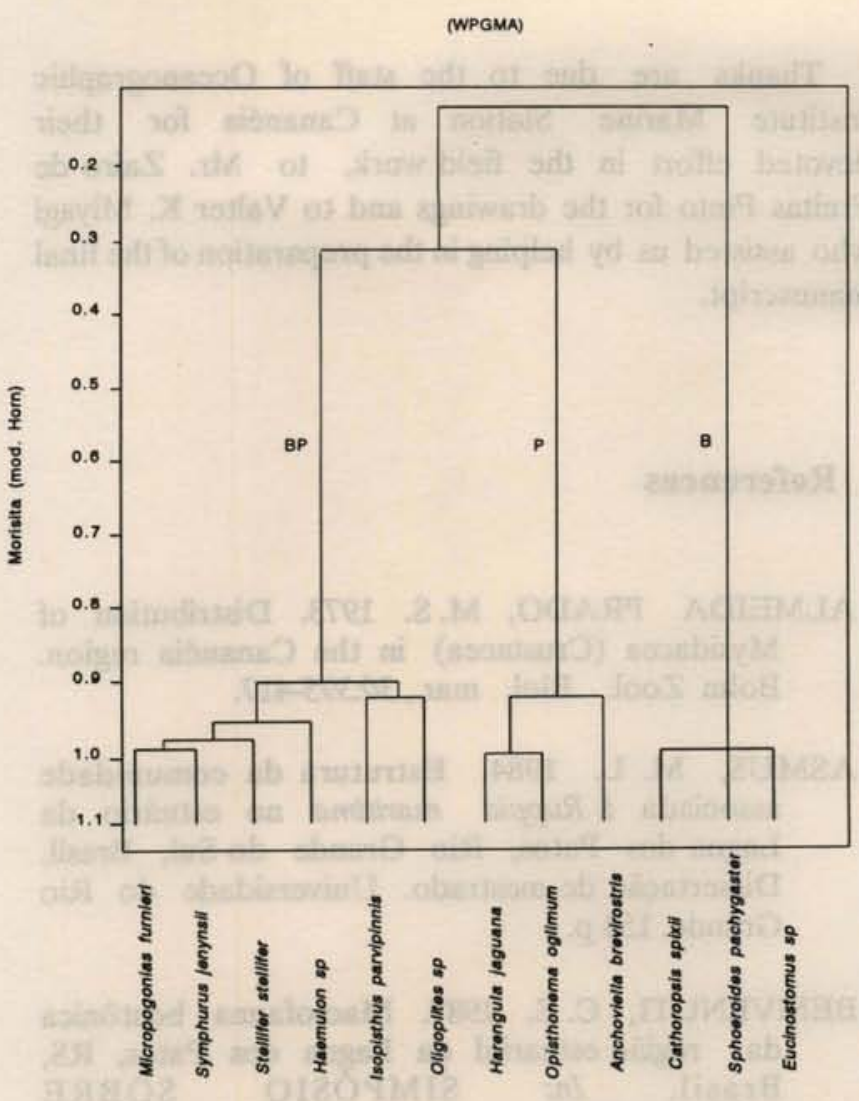

Fig. 12. Cluster analysis based on the similarity of groups of prey habitat $(B=$ benthonic, $P=$ pelagic, $\mathrm{BP}=$ benthopelagic).

Bay, located in the same region. In any case, juvenile of at least 30 species that were captured in the Arrozal use the infralittoral region adjacent to lower marsh habitat, as nursery ground or space for foraging.

We are cognizant of the limitations of the used methodology, such as macrofauna sampling by a dredge, more effective for the epifauna than for the infauna; fishing with a casting and set net; the use of the device including fragments in the food items account; elimination of uncountable organisms of the dredging samples as plants and bryozoans. So, these data do not represent a precise quantitative assessment of fish feeding, but would rather be used as indicator of the relative predation on the local fauna. The estimative of food item fragments by counting parts of specimens was used also by Houston \& Haedrich (1986).

The macrofauna sampling during the period of the study revealed that crustaceans were the most well represented in terms of number of groups. Besides, the groups mysids, copepods and amphipods were the most abundant during certain seasons. Although mysids were present throughout the year, their presence in Spring was conspicuous and consequently, the prey item most readly available and consumed by the fishes of groups I and II. Metamysidopsis elongata atlantica, the most numerous species in the dredging and in fish stomach contents in Cananéia, coincidently revealed its maximum in Spring, according to Almeida Prado (1973). Furthermore, the present data showed that crustaceans are the most abundant group of the fauna.

Table 4. Number of individuals of benthonic (B), pelagic ( $P$ ) and benthopelagic (BP) organisms in the stomach contents of twelve fish species

Fishes

Mumber of organisms

B $P$ BP

\begin{tabular}{lrrr} 
Anchoviella brevirostris & 28 & 917 & 317 \\
Harengula jaguana & 16 & 665 & 2 \\
Opisthonema oglimum & 10 & 1622 & 2 \\
Cathorops spixii & 4027 & 73 & 40 \\
Eucinostomus sp & 121 & 1 & 1 \\
Sphoeroides pachigaster & 66 & 1 & 1 \\
Stellifer stellifer & 444 & 27 & 2256 \\
Haemulon sp & 44 & 1 & 116 \\
Isopisthus parvipinnis & 10 & 9 & 26 \\
Micropogonias furmieri & 319 & 2 & 3100 \\
Oligoplites sp & 8 & 1035 & 2725 \\
Symphuns jenynsii & 16 & 2 & 818 \\
\hline
\end{tabular}

Concerning the three trophic habits fish groups, the first and the third prefer respectively mysids and copepods and the second, the largest one with a rather balanced diet, following the seasonal variation of the fauna. The differences observed within diets of fish may result from the influence of several factors related to prey and predators such as morphology, activities, distribution and abundance and those as availability and acessibility related to the prey. In relation to predation on benthic macrofauna, the epifaunal crustaceans and tanaids were more predated than the infauna as molluscs and polychaetes. This fact has already been considered by Richards (1963) for demersal juvenile fishes. Orth et al. (1984) and Pollard (1984) in their studies on faunal communities in seagrass beds found that, infauna is generally more protected against predation than epifauna and therefore of minor importance for the fish diet.

The present data revealed differences in fish food preferences but even so predation was heaviest on a very limited number of groups as mysids, copepods 
and the epifaunal crustaceans as amphipods, isopods and infaunal tanaids. The relative percentage of the composition of food items within the stomachs give sign that fish consume less than available in the site. According to Currin et al. (1984) $75 \%$ of organisms present on the marsh surface are not utilized as food in their adult size but only as larvae and juveniles. Some fish consume commonly occurring preys (Wyche \& Shackley, 1986), while others eat their preferential item at disposal. Besides, Moody (1950) and Chao \& Musick (1977) have found that ubiquitous and very abundant prey items as mysids may serve as important food supply for young fishes.

Miller \& Dunn (cit. in: Kennedy (1980)) reported that juvenile Scianidae are trophic generalists and could feed on harpacticoid and calanoid copepods, mysids and epibenthos. Moody (1950) studying young specimens of Cynoscion nebulosus found that their diet consisted of copepods, mysids, carid shrimp and small fishes. Pollard (1984) made some general statements on trophic relationships and one of them was that small crustaceans inhabiting the seagrass were important for the local fish communities.

The twelve fish species, in terms of prey habits revealed to be feeder of benthonic (three species), benthopelagic (six species) and pelagic (three species) organisms.

Our results from Cananéia infralittoral region Arrozal suggest that benthonic and benthopelagic organisms are the major source of food being consumed by $75 \%$ of the macropredator fishes. Besides this fact, these fishes are numerically more abundant than those pelagic feeders.

\section{Conclusions}

The infralittoral region near lower marsh at the Arrozal - Cananéia lagoon estuarine region can be considered as a nursery ground for young fish species.

Crustaceans were the best represented among the local macrofauna, being mysids, copepods, epifaunal crustaceans as amphipods, isopods and infaunal tanaids the most heavely predated groups.

Although the data would be used only as indicator of the relative predation on the macrofauna, because of limitations of the used methodology, we can say that benthonic and benthopelagic organisms are the major food source consumed by $75 \%$ of the fish species while only $25 \%$ of them are pelagic feeders.

\section{Acknowledgements}

Thanks are due to the staff of Oceanographic Institute Marine Station at Cananéia for their devoted effort in the field work, to Mr. Zairo de Freitas Pinto for the drawings and to Valter K. Miyagi who assisted us by helping in the preparation of the final manuscript.

\section{References}

ALMEIDA PRADO, M.S. 1973. Distribution of Mysidacea (Crustacea) in the Cananéia region. Bolm Zool. Biol. mar., 30:395-417.

ASMUS, M. L. 1984. Estrutura da comunidade associada à Ruppia maritima no estuário da Lagoa dos Patos, Rio Grande do Sul, Brasil. Dissertaçāo de mestrado. Universidade do Rio Grande. 154 p.

BEMVENUTI, C.E. 1987. Macrofauna bentônica da regiâo estuarial da Lagoa dos Patos, RS, Brasil. In: SIMPÓSIO SOBRE ECOSSISTEMAS DA COSTA SUL E SUDESTE BRASILEIRA: SÍNTESE DOS CONHECIMENTOS, Cananéia, 1987. São Paulo, Academia de Ciências do Estado de São Paulo. v. 1, p.428-459.

BESNARD, W. 1950. Consideraçōes gerais em torno da regiāo lagunar de Cananéia-Iguape. I. Bolm Inst. paul. Oceanogr., S Paulo, 1:9-26.

BODDEKE, R.; DRIESSEN, G.; DOESBURG, W. \& RAMAEKERS, G. 1986. Food availability and predator presence in a coastal nursery area of the brown shrimp (Crangon crangon). Ophelia, 26:77-90.

BOESCH, D. F. \& TURNER, R. E. 1984. Dependence of fishery species on salt marshes: the role of food and refuge. Estuaries, $7(4 \mathrm{~A}): 460-468$.

BREWER, D. T.; BLABER, S. J. M. \& SALINI, J.P. 1991. Predation on penaeid prawns by fishes in Albatross Bay, Gulf of Carpentaria. Mar. Biol., 109:231-240.

CAPITOLI, S. M. N. 1982. Benthic-demersal interespecific trophic relationships in the mixohaline area of the Patos Coastal Lagoon (Brazil). Atântica, Rio Grande, 5(2):22. 
CASTELLO, J. P. 1985. La ecologia de los consumidores del estuario de la Lagoa dos Patos, Brasil. In: Yáñez-Arancibia, A., ed. Fish community ecology in estuaries and coastal lagoons: towards an ecosystem integration. México, Unan Press. p.383-406.

CHAO, L. N. \& MUSICK, J. A. 1977. Life history, feeding habits, and functional morphology of juvenile sciaenid fishes in the York River Estuary, Virginia. Fish. Bull. natn. mar. Fish. Serv., U.S., 75(4):657-702.

CORBISIER, T. N. 1989. Aspectos ecológicos das associaçōes de espécies da macrofauna bentônica e avaliação do efeito da predação sobre a sua estrutura na Praia do Codó (Ubatuba, SP, Brasil). Tese de doutorado. Universidade de São Paulo, Instituto Oceanográfico. $88 \mathrm{p}$.

CURRIN, B. M.; REED, J. P. \& MILLER, J. M. 1984. Growth, production, food consumption, and mortality of juvenile spot and croaker: a comparison of tidal and nontidal nursery areas. Estuaries, 7(4A):451-459.

DAUVIN, J. C. 1988. Rôle du macrobenthos dans lalimentation des poissons démersaux vivant sur les fonds de sediments fins de la Manche Occidentale. Cah. Biol. mar., 29:445-467.

GARCIA-OCCHIPINTI, A. 1959. Radiaçāo global e insolaçāo em Cananéia. Contribuições para o estudo de actinometria. Contrçōes Inst. oceanogr. Univ. S Paulo, sér. Oceanogr. fís., (1):1-40.

1963. Climatologia dinâmica do litoral sul brasileiro. Contrçōes Inst. oceanogr. Univ. S Paulo, sér. Oceanogr. fís., (3):1-86.

GUSMÁN-CARCAMO, A. 1980. Observaçōes sobre a fauna bentônica da regiāo de Cananéia ( $\left.25^{\circ} 00^{\prime} S-48^{\circ} 00^{\prime} \mathrm{W}\right)$, Estado de São Paulo. Dissertaçāo de mestrado. Universidade de São Paulo, Instituto Oceanográfico. 61 p.

HECK Jr, K. L. \& ORTH, R. J. 1980. Seagrass habitats: the roles of habitat complexity, competition and predation in structuring associated fish and motile macroinvertebrate assemblages. In: Kennedy, V. S., ed. Estuarine perspectives. New York, Academic Press. p. 449-464.

HETTLER Jr, W.F. 1989. Nekton use of regularlyflooded saltmarsh cordgrass habitat in North Carolina, USA. Mar. Ecol.-Prog. Ser., 56:111-118.
HOUSTON, K. A. \& HAEDRICH, R. L. 1986. Food habits and intestinal parasites of deep demersal fishes from the upper continental slope east of Newfoundland, Northwest Atlantic Ocean. Mar. Biol., 92:563-574.

JACKSON, J. B. C. 1972. The ecology of the molluscs of Thalassia communities, Jamaica, West Indies. II. Molluscan population variability along an environmental stress gradient. Mar. Biol., 14(4):304-337.

JONES, A. R. 1986. Spatial and temporal variations in a community of nektobenthic invertebrates from Moreton Bay, Queensland. Estuar. coast. Shelf Sci., 23:131-146.

KENNEDY, V. S. 1980. Estuarine perspectives. New York, Academic. Press. 533 p.

LASIAK, T.A. 1984. Aspects of the biology of three benthic-feeding teleosts from King's Beach, Algoa Bay. S. Afr. J. Zool, 19(1):51-56.

LIVINGSTON, R. J. 1982. Trophic organization of fishes in a coastal seagrass system. Mar. Ecol.-Prog. Ser., 7:1-12.

MAGLIOCCA, A. \& KUTNER, A. S. 1964. Conteúdo orgânico dos sedimentos de fundo de Cananéia, São Paulo. Contrções Inst. oceanogr. Univ. S Paulo, sér. Oceanogr. fís., (7):1-14.

MANOOCH III, C.S. 1977. Foods of the red porgy, Pagrus pagrus Linnaeus (Pisces: Sparidae), from North Carolina and South Carolina. Bull. mar. Sci, 27(4):776-787.

MISHIMA, M. \& TANJI, S. 1982. Nicho alimentar de bagres marinhos (Teleostei, Arïdae) no complexo estuarino lagunar de Cananéia $\left(25^{\circ} \mathrm{S}-48^{\circ} \mathrm{W}\right)$. Bolm Inst. Pesca, S Paulo, 9:131-140.

; YAMANAKA, N.; PEREIRA, 0. M.; SOARES, F. C.; SINQUE, C.; AKABOSHI, S. \& JACOBSEN, O. 1985. Hidrografia do complexo estuarino lagunar de Cananéia $\left(25^{\circ} \mathrm{S}\right.$, $\left.48^{\circ} \mathrm{W}\right)$, São Paulo, Brasil. I. Salinidade e temperatura (1973 a 1980). Bolm Inst. Pesca, S Paulo, 12(3):109-121.

MIYAO, S. Y. 1977. Contribuição ao estudo da oceanografia física da regiảo de Cananéia (Lat. $25^{\circ} \mathrm{S}$, Long. $48^{\circ} \mathrm{W}$ ). Dissertação de mestrado. Universidade de São Paulo, Instituto Oceanográfico. $87 \mathrm{p}$. 
MIYAO, S. Y.; NISHIHARA, L. \& SARTI, C. C. 1986. Características físicas e químicas do sistema estuarino-lagunar de Cananéia-Iguape. Bolm Inst. oceanogr., S Paulo, 34(1):23-36.

MOODY, W. D. 1950. A study of the natural history of the spotted trout, Cynoscion nebulosus, in the Cedar Key, Florida area. J. Flor. Acad. Sci., 12(3):164-170.

OLIVEIRA, I. R. \& SOARES, L. S. H. 1991. Alimentação de Mugil sp da região estuarino-lagunar de Cananéia, SP. In: ENCONTRO BRASILEIRO DE ICTIOLOGIA, 9., Maringá, 1991. Resumo. Maringá, Sociedade Brasileira de Ictiologia/Fundaçāo Universidade Estadual de Maringá. p.91.

ORTH, R. J.; HECK, Jr, K. L. \& MONTFRANS, J. van 1984. Faunal communities in seagrass beds: a review of the influence of plant structure and prey characteristics on predator-prey relationships. Estuaries, 7(4A):339-350.

POLLARD, D. A. 1984. A review of ecological studies on seagrass-fish communities, with particular reference to recent studies in Australia. Aquat. Bot., 18:3-42.

POXTON, M. G.; ELEFTHERIOU, A. \& MCINTYRE, A.D. 1983. The food and growth of O-group flatfish on nursery grounds in the Clyde Sea area. Estuar. coast. Shelf Sci., 17(3):319- 337.

RAFFAELLI, D. \& MILNE, H. 1987. An experimental investigation of the effects of shorebird and flatfish predation on estuarine invertebrates. Estuar. coast. Shelf Sci., 24:1-13.

REISE, K. 1985. Tidal flat ecology: an experimental approach to species interactions. Berlin, Springer-Verlag. $191 \mathrm{p}$.

RICHARDS, S. W. 1963. The demersal fish population of Long Island Sound II. Food of the juveniles from a sand-shell locality. Bull. Bingham oceanogr. Colln, 18:32-71.

SCHAEFFER-NOVELLI, Y; MESQUITA, H. S. L. \& CINTRON-MOLERO, G. 1990 . The Cananéia lagoon estuarine system, São Paulo, Brazil. Estuaries, 13(2):193-203.
STRICKLAND, J.D. H. \& PARSONS, T. R. 1968. A practical handbook of sea water analysis. Bull. Fish. Res. Bd Can., (167):1- 311.

SUBRAHMANYAM, C. B. \& DRAKE, S. H. 1975. Studies on the animal communities in two north Florida salt marshes. I. Fish communities. Bull. mar. Sci., 25(4):445-465.

TAKEDA, A. M. 1988. Estrutura de associaçōes macrobênticas da Spartina alterniflora Loiseleur, 1807 no complexo estuarino-lagunar de Cananéia. Tese de doutorado. Universidade de São Paulo, Instituto Oceanográfico. $70 \mathrm{p}$.

TESSLER, M. G. 1982. Sedimentação atual na regiāo lagunar de Cananéia-Iguape, Estado de São Paulo. Dissertaçāo de mestrado. Universidade de São Paulo, Instituto de Geociências. 2 v.

TOMMASI, L. R. 1970. Observaçōes sobre a fauna bêntica do complexo estuarino lagunar de Cananéia (SP). Bolm Inst. oceanogr., S Paulo, 19:43-56.

WEINSTEIN, M. P. 1979. Shallow marsh habitats as primary nurseries for fishes and shellfish, Cape Fear River, North Carolina. Fish. Bull, 77(2):339-357.

WYCHE, C. J. \& SHACKLEY, S. E. 1986. The feeding ecology of Pleuronectes platessa L., Limanda limanda (L.) and Scophthalmus rhombus (L.) in Carmarthen Bay, South Wales, U.K. J. Fish. Biol., 29:303-311.

ZANI-TEIXEIRA, M. L. 1983. Contribuiçāo ao conhecimento da ictiofauna da Baía de Trapandé, complexo estuarino lagunar de Cananéia, SP. Dissertação de mestrado. Universidade de São Paulo, Instituto Oceanográfico. 83 p.

(Manuscript received 4 June 1993; revised and accepted 28 December 1993) 